\title{
TRANSITIONAL JUSTICE AND ECONOMIC, SOCIAL AND CULTURAL RIGHTS
}

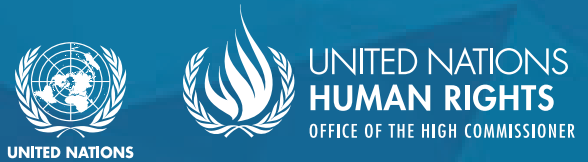




\section{TRANSITIONAL JUSTICE AND ECONOMIC, SOCIAL AND CULTURAL RIGHTS}

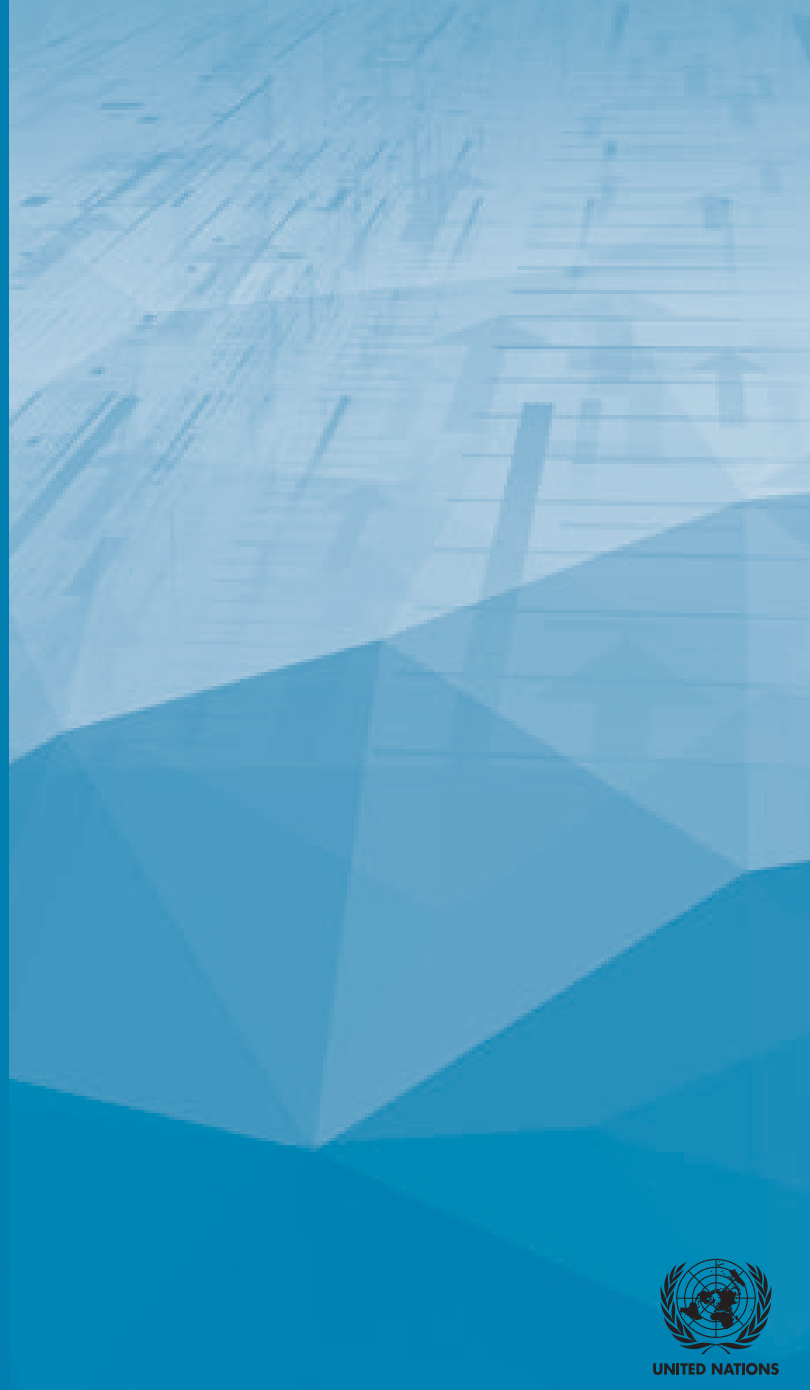




\section{NOTE}

The designations employed and the presentation of the material in this publication do not imply the expression of any opinion whatsoever on the part of the Secretariat of the United Nations concerning the legal status of any country, territory, city or area, or of its authorities, or concerning the delimitation of its frontiers or boundaries.

Symbols of United Nations documents are composed of capital letters combined with figures. Mention of such a figure indicates a reference to a United Nations document. 
INTRODUCTION

I. CONCEPTUAL FRAMEWORK ............................................... 4

A. Transitional justice .............................................. 5

B. International law and economic, social and cultural rights....... 7

II. ADDRESSING ECONOMIC, SOCIAL AND CULTURAL RIGHTS IN SOCIETIES IN TRANSITION .............................................. 16

A. Truth commissions .................................................. 17

B. Judicial and quasi-judicial proceedings .......................... 24

C. Reparations ....................................................... 38

D. Institutional reform................................................... 44

CONCLUSIONS................................................................................... 52 



\section{INTRODUCTION}

In March 2010, the United Nations Secretary-General released his "Guidance Note on the United Nations Approach to Transitional Justice". Its principle 9 calls on the United Nations to "strive to ensure transitional justice processes and mechanisms take account of the root causes of conflict and repressive rule, and address violations of all rights, including economic, social and cultural rights." The Guidance Note further emphasizes that such an approach is needed for peace to prevail.

The Office of the United Nations High Commissioner for Human Rights (OHCHR) has also recognized this need. In 2006, the United Nations High Commissioner for Human Rights, Louise Arbour, already made a call in this sense. She considered that "transitional justice must have the ambition to assist the transformation of oppressed societies into free ones by addressing the injustices of the past through measures that will procure an equitable future. It must reach to-but also beyond-the crimes and abuses committed during the conflict that led to the transition, and it must address the human rights violations that predated the conflict and caused or contributed to it." 1

The failure to realize economic, social and cultural rights as well as violations of these rights can be-and usually are-part of the root causes of conflict. Furthermore, the actions and omissions by States and nonState actors during conflict can also amount to violations of economic, social and cultural rights, and often have a particular impact on the most vulnerable.

Yet, there has been no widespread move to include root causes and violations of economic, social and cultural rights in transitional justice processes. Some argue that, given the exceptional and temporary character of transitional justice mechanisms and their limited human and

Louise Arbour, "Economic and social justice for societies in transition", International Journal of Law and Politics, vol. 40, No. 1 (Fall 2007). See also A/HRC/12/18, paras. 3 and 59-65. 
material resources, further expanding their scope might overburden them and even threaten their very existence.

To address such challenges the following questions must be raised:

(a) What is the potential of transitional justice mechanisms to address these issues?

(b) Are these mechanisms functionally adequate to deal with them?

(c) How best to connect transitional justice and economic, social and cultural rights?

(d) What principles should guide their inclusion in transitional justice processes?

(e) What obstacles should be overcome?

The Office of the United Nations High Commissioner for Human Rights has explored in greater depth the ways in which transitional justice processes have addressed violations of economic, social and cultural rights, so as to gain a better understanding of the potential, challenges and limitations; and to provide stakeholders with recommendations. This publication presents the outcome of that work. 



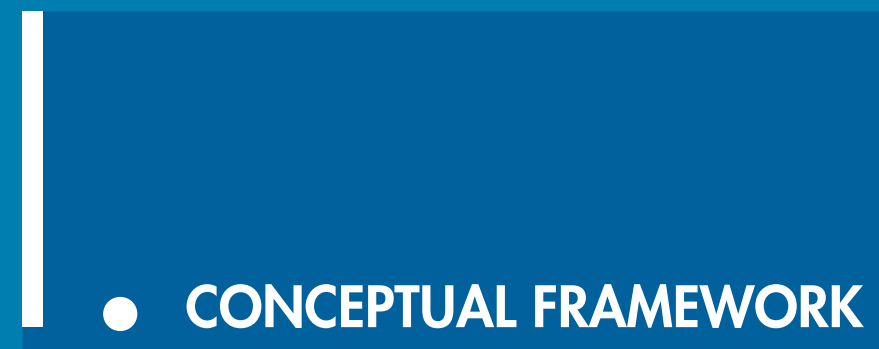


Transitional justice and the protection of economic, social and cultural rights have gained momentum in the past two decades. Nevertheless, little attention has been given to the links between them. This chapter briefly presents both fields so as to clarify how they have developed and how they are linked.

\section{A. TRANSITIONAL JUSTICE}

The United Nations has defined transitional justice as "the full range of processes and mechanisms associated with a society's attempt to come to terms with a legacy of large-scale past abuses, in order to ensure accountability, serve justice and achieve reconciliation."2

United Nations work on transitional justice is based on international human rights law, international humanitarian law, international criminal law and international refugee law.

In particular, four tenets of international human rights law have framed transitional justice and the fight against impunity: (a) the State obligation to investigate and prosecute alleged perpetrators of gross violations of human rights and serious violations of international humanitarian law, including sexual violence, and to punish those found guilty; (b) the right to know the truth about past abuses and the fate of disappeared persons; (c) the right to reparations for victims of gross violations of human rights and serious violations of international humanitarian law; and (d) the State obligation to prevent, through different measures, the reoccurrence of such atrocities in the future.

Different mechanisms or measures have been established to fulfil these obligations: truth-seeking mechanisms such as truth commissions; judicial mechanisms (national, international or hybrid); reparations; and institutional reform, including vetting.

Many of these mechanisms are established with a specific mandate and time frame. Nevertheless, experience shows that temporary and permanent

2 "The rule of law and transitional justice in conflict and post-conflict societies" (S/2004/616), para. 8. 
mechanisms can coexist in an effort to deal with the legacy of abuse and with prevention. Such mechanisms can be international, regional or domestic. For example, the Inter-American Court of Human Rights and some constitutional courts have provided important contributions to transitional justice.

Transitional justice is built on the assumption that social, economic and political changes are possible when significant negotiations of power are taking place in a State. Nevertheless, transitional justice emerged to deal only with a limited dimension of those changes: the legacy of large-scale atrocities and preventing their reoccurrence. While human rights law has strongly influenced transitional justice, the latter has focused on violations of civil and political rights. Transitional justice has, therefore, evolved in relative isolation from important developments in economic, social and cultural rights.

Transitional justice mechanisms may lack economic and human resources and/or moral and political capital. However, experience has shown that even though they face complex challenges, they are necessary and could have a lasting impact on a society-for example, through the official recognition of past violations and by empowering victims. Their contribution to social change may be modest but is important. Taking into consideration the limitations of transitional justice mechanisms, it is essential not to raise unrealistic expectations.

This is particularly true when considering the potential of transitional justice to address violations of economic, social and cultural rights. Although these rights may be included in transitional justice processes, even a successful transitional justice experience will not secure the enjoyment of these rights by everyone. Nevertheless, transitional justice can contribute to the fight against impunity for violations of economic, social and cultural rights, and to their prevention, by laying the foundations for forward-looking reforms and agendas. 


\section{B. INTERNATIONAL LAW AND ECONOMIC, SOCIAL AND CULTURAL RIGHTS $^{3}$}

Economic, social and cultural rights are part of the universal human rights legal framework in which all rights are "universal, indivisible and interdependent and interrelated". ${ }^{4}$ Like civil and political rights, they aim to protect human dignity by establishing both negative and positive obligations for States. Economic, social and cultural rights establish the minimum conditions required for people to live in a dignified way, to ensure freedom from fear and want, and the continuous improvement of these conditions. ${ }^{5}$

Economic, social and cultural rights are enshrined in various international instruments, such as the 1948 Universal Declaration of Human Rights (arts. 22-27) and the 1966 International Covenant on Economic, Social and Cultural Rights.

Both the Declaration and the Covenant provide for the rights to: work, just and favourable conditions of work; form and join trade unions; protection of the family, maternity and childhood; social security; an adequate standard of living, including adequate food, clothing and housing; health; education; take part in cultural life; benefit from scientific progress, and protection of the moral and material interest of authors of scientific, artistic or literary works. The right to property is mentioned in the Declaration and regional human rights treaties and has been interpreted, for example, as protecting housing, indigenous peoples' ancestral territories, indemnities for unfair dismissal and the right to social security.

Many other binding universal human rights instruments also provide for the promotion and protection of economic, social and cultural rights, including: the 1965 International Convention on the Elimination of All

3 See OHCHR Fact Sheet No. 33, Frequently Asked Questions on Economic, Social and Cultural Rights. Available from www.ohchr.org.

4 Vienna Declaration and Programme of Action (A/CONF.157/24 (Part I), chap. III), para. 5.

5 Preamble to the International Covenant on Economic, Social and Cultural Rights. 
Forms of Racial Discrimination; the 1979 Convention on the Elimination of All Forms of Discrimination against Women; the 1989 Convention on the Rights of the Child; the 1990 Convention on the Protection of the Rights of All Migrant Workers and Members of Their Families; and the 2006 Convention on the Rights of Persons with Disabilities. Economic, social and cultural rights also form part of, inter alia, the core conventions of the International Labour Organization (ILO), as well as its 1989 Convention concerning Indigenous and Tribal Peoples in Independent Countries (No. 169), and of the 2007 United Nations Declaration on the Rights of Indigenous Peoples.

Several regional treaties also promote and protect economic, social and cultural rights, such as: the 1961 European Social Charter (revised 1996); the 1988 Additional Protocol to the American Convention on Human Rights in the Area of Economic, Social and Cultural Rights (Protocol of San Salvador); the 1981 African Charter on Human and Peoples' Rights; the 1990 African Charter on the Rights and Welfare of the Child; and the 2003 Protocol to the African Charter on Human and Peoples' Rights on the Rights of Women in Africa. Others focus primarily on civil and political rights, but include some economic, social and cultural rights, or have been interpreted as protecting aspects of economic, social and cultural rights: for example, the 1950 European Convention for the Protection of Human Rights and Fundamental Freedoms and its first Protocol of 1952; the 1969 American Convention on Human Rights and the 1994 Inter-American Convention on the Prevention, Punishment and Eradication of Violence against Women.

Other important treaties incorporate State obligations relevant to economic, social and cultural rights and help to link these rights to transitional justice. For example, the 1948 Convention on the Prevention and Punishment of the Crime of Genocide provides that genocide can be committed by deliberately inflicting on the group conditions of life calculated to bring about its physical destruction in whole or in part-for example, by deliberately depriving the group of the minimum standards of living, such as food.

Important instruments of international humanitarian law establishing obligations for the parties to a conflict (international or non-international) 
are also relevant to economic, social and cultural rights. For example, the four Geneva Conventions of 1949 and the 1907 Hague Regulations contain multiple provisions dealing indirectly with the right to health of the wounded and the sick. The 1977 Additional Protocols I and II to the Geneva Conventions also forbid the starvation of civilians as a method of warfare, as well as attacks on objects indispensable to the survival of the civilian population. Additional Protocol I as well as customary law prohibit attacks directed at civilian objects, including public services infrastructure, which have implications, inter alia, for the rights to education, food, health, housing and water and for cultural rights.

Finally, international refugee law also protects the economic, social and cultural rights of refugees. For instance, the 1951 Convention on the Status of Refugees contains provisions on such rights as the right to work, the right of association and the right to education.

Economic, social and cultural rights are included in a variety of international human rights and humanitarian law instruments, not only in those labelled as such. Many States, including States undergoing transition, have ratified several of these treaties and incorporated economic, social and cultural rights in their constitutions and domestic legislation.

\section{International machinery for the protection of economic, social and cultural rights}

Various international and regional mechanisms have been established to monitor States' compliance with economic, social and cultural rights. At the United Nations, the Committee on Economic, Social and Cultural Rights monitors the compliance of State parties with their obligations under the Covenant. The Committee reviews their periodic reports and issues concluding observations and recommendations. With the entry into force of the Optional Protocol to the Covenant in May 2013, the Committee can also hear individual complaints regarding alleged violations of the Covenant. ${ }^{6}$ Other United Nations treaty-monitoring bodies, the Human

6 The Optional Protocol was adopted on 10 December 2008. 
Rights Council and a number of United Nations special procedures are also part of the international protection framework for economic, social and cultural rights. ${ }^{7}$

While the above-mentioned treaties provide for economic, social and cultural rights and corresponding State obligations, they do not fully explain their content. Therefore, the scope of each economic, social and cultural right needs to be further explained. To this end, the interpretation provided by authoritative bodies such as the Committee and other human rights treaty bodies and special procedures is helpful ${ }^{8}$ and should inform transitional justice stakeholders in their work.

There are regional mechanisms, too: in Europe, the European Court of Human Rights and the European Committee of Social Rights; in the Americas, the inter-American system of human rights, both the Court and the Commission; and in Africa, the African Court on Human and Peoples' Rights and the African Commission on Human and Peoples' Rights.

\section{The nature of international obligations on economic, social and cultural rights}

The Committee on Economic, Social and Cultural Rights has developed several conceptual tools to clarify the nature of economic, social and cultural rights. These tools have been used by international and domestic judicial and quasi-judicial bodies. Some of them are introduced in the following paragraphs.

According to article 2 (1) of the Covenant, "each State Party ... undertakes to take steps, individually and through international assistance and cooperation, especially economic and technical, to the maximum of its available resources, with a view to achieving progressively the full realization of the rights recognized in the present Covenant by all

7 See, generally, www.ohchr.org/EN/HRBodies/SP/Pages/Welcomepage.aspx. In particular, see the work of the special rapporteurs addressing adequate housing, cultural rights, education, food, health, extreme poverty, water and sanitation.

8 For the work of human rights treaty bodies and special procedures, see www.ohchr.org. See also http://uhri.ohchr.org/. 
appropriate means, including particularly the adoption of legislative measures" (emphasis added).

The concept of progressive realization describes a central aspect of States' obligations in connection with economic, social and cultural rights under international human rights treaties. While it recognizes that the full realization of these rights cannot always be achieved immediately and might need time, it requires State parties to take appropriate measures towards full realization to the maximum of their available resources. ${ }^{9}$ The reference to resource availability reflects the recognition that the realization of these rights can be hampered by a lack of resources. Equally, it means that a State's compliance with its obligation to take appropriate measures is assessed in the light of the resources-financial or otherwise-available to it.

However, not all the obligations regarding economic, social and cultural rights are progressive. The Committee has made clear that State parties also have immediate obligations: ${ }^{10}$ the obligation to take deliberate, targeted and concrete steps towards the realization of these rights, the prohibition of discrimination and the adoption of measures to eradicate discrimination in the enjoyment of these rights, the prohibition to adopt retrogressive measures or to infringe economic, social and cultural rights through their action and the obligation to meet the so-called "minimum core obligations" -that is, minimum essential levels of each of the rights. In addition, some of the rights included in the Covenant can be characterized as freedoms - for example, freedom of association and the right to join trade unions - which are of immediate effect and are not particularly resource-intensive.

In order to capture different aspects of the rights enshrined in the Covenant, the Committee has employed a threefold classification of obligations. Accordingly, State parties have obligations to respect, protect and fulfil the rights included in the Covenant. The first require States to refrain from

\footnotetext{
9 See, for example, Committee on Economic, Social and Cultural Rights, general comment No. 3 (1990) on the nature of the State parties' obligations, paras. 4 and 9.

10 Ibid., paras. $1-5$ and 10 .
} 
interfering with the enjoyment of the rights; the second require States to prevent third parties from interfering with the enjoyment of the right; and the third require States to adopt appropriate measures towards the full realization of the right.

The obligation to respect is not subject to progressive realization but is of immediate effect. Regarding economic, social and cultural rights, it prohibits forced evictions, the destruction of houses and other property, forced sterilization, forced labour, intentional famine, gross and systematic discrimination in relation to the right to food, education, health, housing, social security, enjoyment of just and favourable conditions of work, and participation in cultural life.

The State has an obligation to protect individuals from interference by third parties in the enjoyment of their rights. This obligation is generally of immediate effect. While the enjoyment of economic, social and cultural rights is subject to progressive realization, the obligation to fulfil also encompasses some immediate duties-including compliance with minimum core obligations, and the duty to take deliberate and targeted steps to realize the rights. Securing economic, social and cultural rights for vulnerable groups is a particularly important aspect of the obligation to fulfil.

It should be noted that the "respect, protect and fulfil" framework applies equally to civil and political rights, which also entail both positive and negative obligations, for example, the positive obligation to conduct investigations into the circumstances surrounding enforced disappearances. ${ }^{11}$

The principles of equality and non-discrimination are fundamental tenets of international human rights law and are incorporated into most international and regional human rights treaties. For example, article 2 (2) of the Covenant provides that State parties to the Covenant "undertake to guarantee that the rights enunciated in the present Covenant will be

11 European Court of Human Rights, Cyprus v. Turkey, Application No. 25781/94, Judgement of 10 May 2001, paras. 155-158. 
exercised without discrimination of any kind as to race, colour, sex, language, religion, political or other opinion, national or social origin, property, birth or other status." Equality and non-discrimination are also mentioned in the Covenant, including in its article 3, which protects the equal rights of men and women to enjoy all rights prescribed in the Covenant. ${ }^{12}$

The prohibition of discrimination is of immediate effect, given that "discrimination undermines the fulfilment of economic, social and cultural rights for a significant proportion of the world's population." ${ }^{13}$ Discrimination has been defined by the Committee as "any distinction, exclusion, restriction or preference or other differential treatment that is directly or indirectly based on the prohibited grounds of discrimination and which has the intention or effect of nullifying or impairing the recognition, enjoyment or exercise, on an equal footing, of Covenant rights." 14

The obligation not to discriminate under the Covenant implies a negative obligation, as the State should abstain from discriminating against anyone on the grounds enunciated in article 2. It also entails positive obligations, since the State must prevent non-State actors from engaging in discriminatory acts, and "should take concrete, deliberate and targeted measures to ensure that discrimination in the exercise of Covenant rights is eliminated." 15

Systemic discrimination refers to the existence of a general pattern of discrimination against a particular group of people. Apartheid is an example of such systemic discrimination that affected the enjoyment of economic, social and cultural rights in South Africa. The concept of systemic discrimination can be useful to identify relevant criteria for violations of economic, social and cultural rights that might be considered through transitional justice mechanisms.

\footnotetext{
12 See also arts. 7 and 13.

13 Committee on Economic, Social and Cultural Rights, general comment No. 20 (2009) on non-discrimination in economic, social and cultural rights, para. 1.

14 lbid., para. 7.

15 Ibid., para. 36.
} 


\section{Accountability for violations of economic, social and cultural rights}

The protection of human rights requires "that accessible, transparent and effective mechanisms of accountability be established," 16 so that it is possible to monitor compliance and to redress violations. A good system of human rights protection should encompass different forms of accountability, including judicial, political and administrative mechanisms, and independent bodies such as national human rights institutions.

A serious challenge to the enjoyment of economic, social and cultural rights has been the lack of accountability mechanisms. Nevertheless, the past two decades have witnessed an increase in such mechanisms to assess compliance with treaty obligations and to determine and redress violations internationally, regionally and domestically. At the international level, human rights bodies have an accountability role-for example, through the examination of periodic reports by treaty bodies and country visits by special rapporteurs. Some regional mechanisms are also competent to review State parties' compliance and to make recommendations. A number of different techniques-including budget analysis and indicators-have also been developed in recent years to monitor economic, social and cultural rights. Such techniques are increasingly being used to assess the realization of these rights in different national contexts.

The past decades have also witnessed an increase in the use of regional and domestic courts and quasi-judicial mechanisms to address alleged violations of economic, social and cultural rights. This experience has helped to overcome the traditional scepticism about the justiciability of economic, social and cultural rights - that is, the possibility of courts adjudicating these rights. ${ }^{17}$ Regional human rights commissions and courts, such as the Inter-American Commission and Court on Human Rights and the European Committee of Social Rights, have addressed a wide range of violations

16 Hunt and Leader, "Developing and applying the right to the highest attainable standard of health".

17 Malcolm Langford, "The justiciability of social rights: from practice to theory", in Social Rights Jurisprudence: Emerging Trends in International and Comparative Law, M. Langford, ed. (Cambridge, Cambridge University Press, 2008). 
of economic, social and cultural rights. Various domestic courts and national human rights institutions have developed expertise in considering complaints for alleged violations of these rights and tailoring adequate remedies or recommendations to redress them. The Optional Protocol to the Covenant allows the Committee to consider complaints based on alleged violations of the rights included in the Covenant, and thus offers a universal forum for the consideration of violations of economic, social and cultural rights. 
- ADDRESSING ECONOMIC, SOCIAL AND CULTURAL RIGHTS IN SOCIETIES IN TRANSITION 
This chapter explores transitional justice experiences where violations of economic, social and cultural rights led to and/or occurred during the conflict, with a view to identifying challenges, achievements and limitations.

\section{A. TRUTH COMMISSIONS}

Truth commissions could be suitable platforms for considering the root causes of conflict or repression and violations of economic, social and cultural rights, given their aim to uncover the truth about past events and their mandates to examine the causes, consequences and nature of gross human rights violations. While seeking the truth might have a narrower or broader scope, a holistic account of the truth includes the root causes as well as all large-scale violations of human rights that took place, including those of economic, social and cultural rights. ${ }^{18}$

The majority of truth commissions have focused on violations of civil and political rights owing to their limited mandates but have given some attention to the root causes of conflict or repression and have, therefore, considered issues that affect the enjoyment of economic, social and cultural rights. This has been reflected in their conclusions and recommendations. ${ }^{19}$ Exceptionally, truth commissions have dealt with violations of these rights but they have not done so exhaustively.

\section{The Commission for Reception, Truth and Reconciliation in Timor-Leste}

The 2005 final report of the Commission for Reception, Truth and Reconciliation in Timor-Leste constitutes an important effort to consider violations of economic, social and cultural rights as well as the root causes of the conflict. This Commission had a wide mandate to "[inquire] into and [establish] the truth regarding human rights violations which took place in the context of the political conflicts in Timor-Leste between 25 April 1974

\footnotetext{
18 Arbour, "Economic and social justice", p. 14.

19 P. Hayner, Unspeakable Truths: Transitional Justice and the Challenge of Truth Commissions, $2^{\text {nd }}$ ed. (New York, Routledge, 2011 ), p. 77.
} 
and 25 October 1999." This mandate included looking into the "context, causes, antecedents, motives and perspectives which led to the violations." 20

The Commission's report includes a satisfactory account of the root causes of the political conflict. It looked into Timor-Leste's colonial history under Portuguese rule as well as the occupation by Indonesia and its history of resistance. Furthermore, the Commission considered the role of various actors in the political conflict to avoid an incomplete account of what happened. ${ }^{21}$ It considered the violations committed by Timor-Leste and Indonesia and the role of other actors such as corporations, members of opposition groups and political parties.

The regulation that established the Commission contained a broad definition of human rights violations. It indicated that such violations could be of three types: violations of international human rights standards; violations of humanitarian law; and criminal acts. The Commission acknowledged that this included violations of economic, social and cultural rights set forth in the Universal Declaration of Human Rights, the International Covenant of Economic, Social and Cultural Rights, the International Convention on the Elimination of All Forms of Racial Discrimination, the Convention on the Elimination of All Forms of Discrimination against Women, and the Convention on the Rights of the Child. ${ }^{22}$

Owing to resource constraints, the Commission focused on the human rights that were the most affected during the occupation, including economic, social and cultural rights. It found that, out of 102,800 deaths in the period covered, 18,600 amounted to killings, while the rest resulted from hunger and illness. ${ }^{23}$ It devoted one full section of its final report to the human rights violations involved in those deaths related to hunger and illness. ${ }^{24}$

\footnotetext{
20 "Chega! The report of the Commission for Reception, Truth and Reconciliation in TimorLeste (CAVR)", part 2, para. 2.1.

21 Ibid., part 2, para. 8.

22 Ibid., paras. 10-16.

23 Ibid., part 6, para. 8.

24 Ibid., part 7, chap. 7.9.
} 
In considering economic, social and cultural rights, the Commission took a three-pronged approach. First, it looked directly at violations of economic, social and cultural rights, and considered the consequences of violations of civil and political rights for these rights. Second, it considered violations of international human rights and international humanitarian law. In particular, it referred to rights under the Covenant (not ratified by Indonesia) and, as Indonesia was the occupying Power in Timor-Leste, the Commission also referred to provisions of the fourth Geneva Convention of 1949 and the 1907 Hague Regulations which relate to economic, social and cultural rights. Third, in considering rights under the Covenant, the Commission followed the conceptual framework of the Committee on Economic, Social and Cultural Rights, and the views expressed in its general comments Nos. 3 and 12-15.

The Commission found violations of the right to an adequate standard of living, and the rights to health and education. It considered that, as an occupying Power, Indonesia discriminated against the Timorese and also failed "to provide for certain basic needs, such as food, shelter, essential medicines and basic education." It also concluded that it failed to comply with its obligations to the maximum of its available resources and that it even engaged in retrogressive measures. ${ }^{25}$ The Commission acknowledged that its work on cultural rights was limited owing to resource constraints. It dealt with them but "only to the extent that they [were] inseparable from violations of social and economic rights." 26

The Commission faced obstacles in dealing with these violations, especially the lack of reliable data for the period of time it was examining (19741999). According to the Commission, "because of the closed nature of East Timor under the occupation and because research during that period focused on the urgent need to halt the massive abuses of civil and political rights, social and economic data are only spottily available. Economic data that are available vary widely in quality and need to be treated with caution." Therefore, the sources it used were interviews and secondary data. ${ }^{27}$

\footnotetext{
25 Ibid., paras. 7-9.

26 Ibid., para. 12.

27 Ibid., para. 10.
} 
In its final report, the Commission made recommendations on economic and social rights: ${ }^{28}$ for example, that Timor-Leste should provide adequate conditions of detention to prisoners such as medical care and water; that an inquiry should be initiated into land disputes as a result of resettlement programmes; and that a national day should be established to remember the famine of 1978-1979, when many died. Cultural rights were also mentioned. The Commission considered that East Timorese culture should be protected and used as a "source of national identity" through different means.

\section{The Sierra Leone Truth and Reconciliation Commission}

The Sierra Leone Truth and Reconciliation Commission also constituted an important attempt to deal with violations of economic, social and cultural rights and the root causes of conflict or repression. In accordance with the Truth and Reconciliation Commission Act 2000, it was mandated "to create an impartial historical record of violations and abuses of human rights and international humanitarian law related to the armed conflict" from 1991 to the signing of the Lomé Peace Agreement. To that end, it was to look into "the causes, nature and extent of the violations ... [and] the context in which the violations ... occurred" as well as into the role played by different actors (not only States) in the conflict. Its final report, "Witness to truth", was released to the public in 2004.

The Commission looked into the root causes of the conflict, identifying trends that divided the country and political decisions that benefited the elite, and considering particular events. ${ }^{29}$ It looked at the role of mineral resources, in particular diamonds, in fuelling the conflict $^{30}$ and at the responsibility of external actors such as the National Patriotic Front of Liberia, Charles Taylor and Libya. It found that the conflict was possible because of the "endemic greed, corruption and nepotism that deprived the nation of its dignity and reduced most people to a state of poverty. ${ }^{\prime 31}$

\footnotetext{
28 Ibid., part 11.

29 "Witness to Truth: Report of the Sierra Leone Truth and Reconciliation Commission", vol. 2.

30 Ibid., vol. 3 B, chap. 1.

31 Ibid., vol. 2, chap. 2, para. 13.
} 
To carry out its human rights mandate, the Commission adopted categories of violations, including "economic violations", 32 such as looting, destruction of property and extortion. ${ }^{33}$ It also looked at the economic, social and cultural dimensions of some violations as they affected women and children.

Unfortunately, unlike the Commission for Reception, Truth and Reconciliation in Timor-Leste, the Sierra Leone Truth and Reconciliation Commission did not use, in its analysis of economic, social and cultural rights violations, relevant concepts such as minimum core obligations, which could have strengthened its findings.

\section{The Guatemalan Commission of Historical Clarification}

While the Guatemalan Commission of Historical Clarification, ${ }^{34}$ which released its report in 1999, was not explicitly mandated to look into the root causes of conflict, it dedicated chapter one of its report to this issue. ${ }^{35}$ The Commission looked in particular at violations of civil and political rights. Nevertheless, since it noted that acts of genocide had taken place against the indigenous Mayan communities, ${ }^{36}$ affecting their traditions, it looked into violations of cultural rights and their impact, including on the Mayan population's enjoyment of decent standards of living.

The Commission referred to different international instruments that protect the right to cultural identity, including ILO Convention No. 169, the Convention on the Prevention and Punishment of the Crime of Genocide, the International Covenant on Civil and Political Rights and the American Convention on Human Rights. The Commission acknowledged that racism and discrimination were key factors in the atrocities that took place against the Mayan population. It also concluded that, during the internal conflict,

32 Ibid., vol. 3 A, chap. 4, para. 14.

33 Ibid., para. 19.

34 Acuerdo sobre el Establecimiento de la Comisión para el Esclarecimiento Histórico de las Violaciones a los Derechos Humanos y los Hechos de Violencia que han Causado Sufrimientos a la Población Guatemalteca, 23 June 1994.

35 "Guatemala: Memoria del silencio", vol. I, chap. I.

36 Ibid., vol. III, chap. XVIII, paras. 2866-2950. 
the State had deprived indigenous peoples of their traditional economic activities, caused their forced displacement, affected their survival and culture, and forced them into conditions of extreme poverty. ${ }^{37}$

\section{Addressing economic crimes: Truth and Reconciliation Commission of Liberia}

Other truth commissions have dealt with the economic and social implications of conflict or repression without explicit reference to the human rights framework. For example, some truth commissions opted to look at economic crimes ${ }^{38}$ and/or corruption. ${ }^{39}$

Investigating economic crimes is not the same as investigating violations of economic, social and cultural rights, even if the two are related. Rights are entitlements of individuals or groups that create obligations for States. Failure to comply with them engages the international responsibility of the State. Economic crimes look at individual or corporate criminal responsibility. However, States may be unable to comply with their international obligations if economic crimes and corruption affect the availability of State resources. Furthermore, State agents may be involved in economic crimes or turn a blind eye. Such behaviour could engage the international responsibility of the State if, as a result of such conduct, the State fails to comply with its human rights obligations. Therefore, while truth commissions could also consider economic crimes, this should occur alongside the examination of violations of economic, social and cultural rights.

In Liberia, the Truth and Reconciliation Commission was mandated to investigate gross human rights violations, violations of humanitarian law and "economic crimes, such as the exploitation of natural or public resources to perpetuate armed conflicts", and determining those responsible..$^{40}$ It defined

37 Ibid., paras. 2887-2901 and 2904-2909.

38 Report of the Truth and Reconciliation Commission of Liberia, vol. 3, title III.

39 For example, "Chad: Report of the Commission of Inquiry into the crimes and misappropriations committed by ex-President Habré, his accomplices and/or accessories: investigation of crimes against the physical and mental integrity of persons and their possessions", 7 May 1992.

402005 Act to Establish the Truth and Reconciliation Commission (TRC) of Liberia. 
economic crimes as any prohibited activity aimed at generating economic gain by a State or non-State actor whose economic activities fuelled the conflict, or contributed to gross human rights and/or humanitarian law violations, or who benefited economically from the conflict; or any activity of a public or private person aimed at generating illicit profit by engaging in conduct such as tax evasion, money laundering, looting, human trafficking and child labour. ${ }^{41}$

The Commission considered diverse economic crimes and their perpetrators (many of them companies) in different economic sectors such as timber, logging and mining; and also looked at the role of corruption. In its analysis, it noted the role played by the State in these crimes. However, it did not take the opportunity to account for Liberia's responsibility under human rights law, even when some of the so-defined economic crimes also amount to human rights violations.

The Commission also highlighted that economic crimes involved violations of the principles of equality and non-discrimination. For example, companies applied different labour standards to workers based on national grounds, and the State did not prevent such behaviour, thereby violating its obligation to protect people from being discriminated against so that they can enjoy their right to equal salary for equal work. ${ }^{42}$

The Commission concluded that "the appalling number and scale of economic crimes in Liberia has grossly deprived Liberia and Liberian citizens of their economic rights and has obstructed the economic development and policy of the State."43 Although the Commission did not consider violations of economic, social and cultural rights in detail, it did recommend that Liberia should ratify the Optional Protocol to the Covenant. ${ }^{44}$

41 Report of the Truth and Reconciliation Commission of Liberia, vol. 2, sect. 9.9. 1. It should be noted that some of these, such as child labour and human trafficking, constitute human rights violations on their own. They were, however, labelled as "economic crimes" by the Commission.

42 Ibid., vol. 3, title III, para. 72.

43 lbid., para. 138.

44 Ibid., vol. 2, sects. 18.4 and 18.5 . 


\section{B. JUDICIAL AND QUASI-JUDICIAL PROCEEDINGS}

Prosecutions of international crimes are central to transitional justice. Human rights courts have also contributed to the fight against impunity. They coexist with and complement the work of criminal courts.

While these justice mechanisms (criminal or civil) face jurisdictional and other limitations, they can constitute a useful avenue to address violations of economic, social and cultural rights and/or the root causes of conflict or repression. Human rights courts can, in principle, adjudicate violations of economic, social and cultural rights, provided that their constitutive instruments refer to these rights. In contrast, criminal courts can address violations of economic, social and cultural rights (or some aspects thereof), provided that the violations are legally defined as crimes. Indeed, a number of international crimes involve or might involve infringements of economic, social and cultural rights. ${ }^{45}$ The following sections illustrate how, despite such limitations, courts have addressed root causes and/or violations of economic, social and cultural rights.

\section{Accountability for human rights violations}

Human rights courts, regional and domestic, have adjudicated on economic, social and cultural rights, even if not always in the context of transitional justice. Significant jurisprudence related to economic, social and cultural rights in a transitional justice context can be found in the judgements of the InterAmerican Court of Human Rights, the Human Rights Chamber for Bosnia and Herzegovina, the Constitutional Court of Colombia and, although not a court, in the reports of the African Commission on Human and Peoples' Rights.

\section{(a) The Inter-American Court of Human Rights}

The Inter-American Court of Human Rights has adjudicated on several cases involving large-scale abuses which occurred during conflict or repression.

45 For instance, article 8 (2) (b) (ix) of the Rome Statute of the International Criminal Court includes in the definition of war crimes "intentionally directing attacks against buildings dedicated to religion, education, art, science or charitable purposes, historic monuments, hospitals and places where the sick and wounded are collected, provided they are not military objectives". Some of these may amount, directly or indirectly, to infringements of economic, social or cultural rights. 
Such cases often arrived at the Court when the States concerned had undergone or were undergoing a transition.

This jurisprudence has not addressed the root causes of conflict or repression but has shown that clarifying the factors that fuel conflict or repression - such as the creation of paramilitary groups or land disputescould help adjudication. Indeed, the Court usually seeks to describe the context in which violations took place. ${ }^{46}$ This has helped to argue the existence of patterns of violations in cases against Chile, ${ }^{47}$ Colombia, ${ }^{48}$ Guatemala ${ }^{49}$ and Peru. ${ }^{50}$ Furthermore, the Court takes stock of the work of truth commissions and other transitional justice mechanisms.

The Court's jurisprudence has addressed violations of economic, social and cultural rights in different ways. First, it has interpreted civil and political rights in such a way as to protect economic, social and cultural rights. For example, in the case of the Mapiripán Massacre, ${ }^{51}$ the Court used an expansive interpretation of the right to life to protect, among other things, the rights to food, housing and health of the victims of the massacre and massive displacement when arguing that the State has the obligation to adopt positive measures to ensure a dignified life.

The Court also linked its consideration of the alleged violations of the rights of the child (art. 19) and of freedom of movement (art. 22) to the right to life (art. 4) under the American Convention on Human Rights. The Court argued that these rights were violated because Colombia failed to discharge its positive obligations to provide children and displaced people with the necessary conditions to live in dignity. For the Court, these vulnerable groups saw their families disintegrate, witnessed the massacre,

46 Goiburú et al. v. Paraguay, Judgement of 22 September 2006, Series C, No. 153, paras. 61-61 (125). See also separate opinion of Judge A. A. Cançado Trindade.

47 Almonacid-Arellano et al. v. Chile, Judgement of 26 September 2006, Series C, No. 154.

48 Rochela Massacre v. Colombia, Judgement of 11 May 2007, Series C, No. 163.

49 Las Dos Erres Massacre v. Guatemala, Judgement of 24 November 2009, Series C, No. 211.

50 La Cantuta v. Peru, Judgement of 29 November 2006, Series C, No. 162.

51 Mapiripán Massacre v. Colombia, Judgement of 15 September 2005, Series C, No. 134. See, in particular, paras. 96.30-96.67, 161-162, 175, 180 and 186. 
were forced into poverty, lost their homes and jobs, faced the threat of serious illnesses and lacked access to food. This happened in the face of inaction by the State authorities. While this case identified the vulnerable conditions in which victims had to survive, it did not detail the positive obligations deriving from the right to life of relevance to economic, social and cultural rights.

The case of Ituango Massacres v. Colombia, ${ }^{52}$ on the other hand, exemplifies the direct justiciability of economic, social and cultural rights. The case relates to the execution of 19 inhabitants of Aro and Granja, in ltuango, by paramilitaries acting with the support of members of the military. In addition to the executions, many people were forcibly displaced. The Court held that the State authorities had failed to protect the population during and after the paramilitary incursions in Ituango. Furthermore, in Aro, most houses were burned down and cattle and other livestock stolen. For several days residents of the area were forced to herd cattle without remuneration. Army members imposed a curfew to facilitate the transfer of the stolen livestock without witnesses.

The applicants alleged that the State had violated the prohibition of slavery and forced or compulsory labour (art. 6), given that some victims were coerced to herd livestock under threat of death. The Court interpreted article 6 of the American Convention on Human Rights in the light of ILO Convention No. 29 concerning Forced or Compulsory Labour, ratified by Colombia in 1969. Therefore, forced labour entails three elements: the menace of a penalty, involuntary labour and State participation or acquiescence. As all three elements were satisfied in this case, the Court held that the State had violated article 6 (2) of the American Convention on Human Rights.

In addition to labour rights, the Court also found a violation of the right to property (art. 21). The Court has interpreted this right to include all possessions of a person (material or immaterial, movable or immovable)

52 Ituango Massacres v. Colombia, Judgement of 1 July 2006, Series C, No. 148. See in particular paras. 125 (79), 125 (81)-125 (82), 125 (85), 133, 141, 156-157, 160, 174,178 and 180 . 
such as houses, cattle and other livestock and communal and ancestral land. The Court also referred to Additional Protocol II to the Geneva Conventions-applicable to non-international armed conflict-which prohibits the destruction or removal of "objects indispensable to the survival of the civilian population" (art. 14).

For the Court, the theft of between 800 and 1,200 head of livestock was particularly serious given the "close relationship between the [victims] and their livestock, because their main means of subsistence was cultivating the land and raising livestock." 53 Equally serious was the destruction of houses. Such acts damaged the social framework of the community and caused "an important financial loss" that affected the victims' most "basic living conditions." 54

\section{(b) The Human Rights Chamber for Bosnia and Herzegovina}

Annex 6 to the Dayton Peace Agreement of 1995 foresaw the establishment of a Commission on Human Rights in Bosnia and Herzegovina to honour human rights. The Commission would consist of an Office of the Ombudsman and a Human Rights Chamber (art. II). The latter would have jurisdiction over: violations of the European Convention for the Protection of Human Rights and Fundamental Freedoms, its Additional Protocols; and alleged or apparent discrimination on any ground, where such violation is alleged or appears to have been committed by the Parties to the detriment of any of the rights or freedoms established in the appendix to annex 6, including relevant treaties on economic, social and cultural rights such as the Covenant and the Convention on the Prevention and Punishment of the Crime of Genocide. ${ }^{55}$

By 2003, when the Chamber ceased to function, it had considered more than 15,000 cases, the majority of which concerned violations of

53 lbid., para. 178.

54 lbid., para. 182.

55 Article II and the appendix provide for jurisdiction over discrimination on grounds of sex, race, colour, language, religion, political or other opinion, national or social origin, association with a national minority, property, birth or other status. 
economic and social rights; it also decided a smaller number of cases on cultural rights. In particular, the Chamber dealt with cases relating to the right to property and restitution, but also with the rights to work, education and social security. ${ }^{56}$

During the war, more than 2 million people were displaced (about half the overall population at the time) as a result of ethnic cleansing, resulting in the loss of property (occupied or owned), affecting their right to housing and property. Therefore, annex 7 to the Dayton Peace Agreement, on refugees and displaced persons, included the right to return and to property restitution or, if that was not possible, to compensation. The Chamber played a key role in addressing housing and property rights, given that article 8 of the European Convention on Human Rights contains the right to respect for private and family life, including the right to respect for the home, and article 1 of its first Protocol incorporates the right to property. These articles permit the justiciability of the right to property.

The following case illustrates the significance of the Chamber's decisions in this area. In M.J. v. Republika Srpska, the Chamber had to decide whether a mere occupancy right over property was protected under the European Convention on Human Rights and its first Protocol. The case concerned M.J., a citizen of Bosnia and Herzegovina of Bosniak descent, who claimed "occupancy rights" over an apartment in Banja Luka. M.J. and his family were evicted from the apartment by a Serbian refugee in 1995. The applicant initiated court proceedings but court orders were not enforced. ${ }^{57}$

Since occupancy rights were general practice in Bosnia and Herzegovina, the views of the Chamber were to have a significant impact on the restitution

56 See Kličković et al. v. Bosnia and Herzegovina, the Federation of Bosnia and Herzegovina, and the Republika Srpska, Nos. CH/02/8923, CH/02/8924 and CH/02/9364, decision of 10 January 2003, para. 15; Šećerbegović et al. v. Bosnia and Herzegovina and the Federation of Bosnia and Herzegovina, Nos. CH/98/706, CH/98/740 and $\mathrm{CH} / 98 / 776$, decision of 7 April 2000; and Mitrović v. the Federation of Bosnia and Herzegovina, No. CH/98/948, decision of 6 September 2002, para. 54.

57 M.J. v. Republika Srpska, No. CH/96/28, decision of 7 November 1997, in particular paras. 6-11 and 32-33. 
of lost properties. The rights holders could live and enjoy the property indefinitely and the occupancy right could be inherited. The Chamber found that occupancy rights were protected, inter alia, under article 1 of the first Protocol to the European Convention on Human Rights. For the Chamber, such right is a "valuable asset" that "constitutes a 'possession' within the meaning of article 1 as interpreted by the European Commission and Court." According to this article, "every ... person is entitled to the peaceful enjoyment of his possessions." The Chamber found a breach of this right as the lack of enforcement of court orders constituted a "failure by the authorities to protect the applicant against unlawful interference with his possessions by private individuals". Other decisions by the Chamber complement this groundbreaking judgement. ${ }^{58}$

\section{(c) The Colombian Constitutional Court}

The Colombian Constitutional Court has decided important cases on economic, social and cultural rights in the context of the implementation of the Justice and Peace Law (a transitional justice framework in Colombia), while also developing some of its previous jurisprudence on these rights.

In the case of internally displaced persons (IDPs), ${ }^{59}$ decided before the Justice and Peace Law came into force, the Court declared that internal displacement in Colombia constituted a violation of multiple human rights. It also concluded that the lack of a coherent and holistic public policy to deal with the second highest population of IDPs in the world amounted to an unconstitutional state of affairs given the failure of the State authorities to respect, protect and fulfil the rights of displaced persons.

The Court ordered the Government to redesign its policy on IDPs and to fulfil, in all circumstances, "certain minimum rights." For the Court, this meant that the minimum core fundamental rights should be respected and that all those other rights "which are intrinsically connected to the

58 Kevešević v. the Federation of Bosnia and Herzegovina, No. CH/97/46, decision of 15 July 1998; Onić v. the Federation of Bosnia and Herzegovina, No. CH/97/58, decision of 12 February 1999.

59 T-025/04, Judgement of 22 January 2004, in particular sect. 9. 
preservation of life in dignity" should also be fulfilled. The Court listed different rights in line with the Constitution and the Guiding Principles on Internal Displacement, including the right to a minimum standard of living; health; non-discrimination; education for children until the age of 15; work and return in safety and dignity.

The Court has used public hearings and follow-up orders to monitor compliance with its judgement. For example, in Order 092/08, ${ }^{60}$ dealing with internally displaced women, the Court ordered the State to establish gender programmes, some of which aimed to ensure economic, social and cultural rights such as health programmes, psychosocial support and education programmes for women over the age of 15 .

The case of El Salado61 builds on and develops the content of Order 092/08. In this case, applicants alleged that their right to health under the Constitution had been breached by the Ministry of Social Protection, which failed to take the necessary measures to ensure that four female victims of two massacres in El Salado, who were also internally displaced, were provided with physical and psychological treatment. The applicants suffered severe psychological harm as a result of the violence they witnessed and their ongoing mistreatment by the State authorities.

The victims were not able to enjoy their constitutional right to health because of bureaucratic obstacles, lack of relevant information about services and lack of access to specialized treatment and medicines. This meant that their economically disadvantaged families had to pay for some of these services and medicines.

The Court recalled that the right to health has to be fulfilled bearing in mind availability, accessibility, acceptability and quality of services and facilities, but emphasized that the particular circumstances of each case should be taken into account, including the poverty of victims and the suffering experienced by their families. This translates, for example, into

60 Order (auto) 092/08 of 14 April 2008, in particular sect. V.A.7.

$61 \mathrm{~T}-045 / 10$, Judgement of 2 February 2010. 
a State obligation to provide extra health services to victims who are not covered by the national health programme and to treat mental illness from a psychosocial perspective.

This case exemplifies Colombia's failure to respect and to fulfil the right to health of internally displaced women. Importantly, the Court identified key aspects of the State's obligations, including: carrying out a medical assessment of the mental and physical health needs of the women, including the views of psychosocial experts, so as to identify the treatment and action to be taken; providing expert medical treatment (for physical and mental health) and free medicines to the victims for as long as necessary; ensuring a national health system that covers transport, accommodation and other expenses necessary to access specialized treatment.

\section{(d) The African Commission on Human and Peoples' Rights}

Other quasi-judicial bodies like the African Commission on Human and Peoples' Rights have also dealt with violations of economic and social rights in the context of transitions. A case in point is COHRE v. Sudan, ${ }^{62}$ in which the applicants alleged, inter alia, that the Sudan's campaign had targeted the civilian population in Darfur, that villages, markets and water wells had been raided, and that many residents had been forcibly evicted, and their homes and other structures totally or partially burned or destroyed.

The Commission found several violations. It considered that the right to health under the African Charter had been breached, given that "the destruction of homes, livestock and farms as well as the poisoning of water sources, such as wells, exposed the victims to serious health risks." It arrived at this conclusion based on general comment No. 14 (2000) of the Committee on Economic, Social and Cultural Rights on the right to the highest attainable standard of health, which specifies that the right to health extends "not only to timely and appropriate health care but also to

62 Sudan Human Rights Organisation and Centre on Housing Rights and Evictions (COHRE)/Sudan, Communications Nos. 279/03 and 296/05, decision of May 2009. See in particular paras. 9-14, 205, 209 and 212. 
the underlying determinants of health, such as access to safe and potable water ..., an adequate supply of safe food, nutrition and housing."

The Commission also relied on the right to property in finding violations of the right to housing as the Sudan had "failed to show that it refrained from the eviction, or demolition of victims' houses and other property. It did not take steps to protect the victims from the constant attacks and bombings, and the rampaging attacks ... the fact that the victims cannot derive their livelihood from what they possessed for generations means they have been deprived of the use of their property under conditions which are not permitted by article 14 [of the African Charter of Human and Peoples' Rights]."

\section{Accountability for international crimes}

Generally, criminal tribunals dealing with large-scale atrocities in processes of transition have jurisdiction over international crimes such as genocide, crimes against humanity and war crimes. Several of these crimes are related to violations of economic, social and cultural rights, and this has been reflected in the jurisprudence of international and hybrid criminal tribunals.

\section{(a) Crimes against humanity}

Some internationally recognized crimes against humanity encompass largescale violations of economic, social and cultural rights. The jurisprudence of international criminal tribunals has relied on the underlying offence of persecution on political, racial, ethnic or religious grounds. ${ }^{63}$

Notably, the Trial Chamber of the International Criminal Tribunal for the former Yugoslavia considered economic, social and cultural rights within the scope of persecution as a crime against humanity in the Kupreškić case. ${ }^{64}$ The prosecution argued that persecution could entail additional grounds to those listed in article 5 of the Tribunal's Statute (political,

63 See also additional grounds included in the definition of persecution in the Rome Statute, art. 7 (1) (h).

64 Prosecutor v. Kupreškić et al., No. IT-95-16-T, Trial Chamber, Judgement of 14 January 2000. See in particular paras. 610-613, 615 (c), 618, 621 and 630-631. 
racial or religious grounds). The Chamber agreed and considered that infringement of housing, health, education and cultural rights could also amount to persecution, maintaining that persecution could involve attacks on political, social and economic rights.

According to the Chamber, not every discriminatory denial of a fundamental right gives rise to a crime against humanity, only discriminatory denial of rights "laid down in international customary or treaty law" that is "gross or blatant". Furthermore, the breaches should be of the "same level of gravity as the other acts prohibited in article 5."

The Chamber referred explicitly to the Universal Declaration and both United Nations Covenants as the sources of rights that are relevant when considering whether persecution has taken place. It concluded that the destruction of Bosnian Muslim homes and property could constitute persecution as a crime against humanity since it might entail "a destruction of the livelihood of a certain population." This conclusion was reiterated in Kordić and Čerkez. ${ }^{65}$

The case of Krajišnik ${ }^{66}$ also illustrates the relevance of violations of economic, social and cultural rights in the context of ethnic cleansing in Bosnia and Herzegovina. The Chamber found that there had been unfair dismissal of people from public jobs, forced labour, lack of access on equal grounds to public services, inhuman living conditions in detention places, appropriation and plunder of property and destruction of private property.

Equally, in Brđanin, ${ }^{67}$ the Chamber held that detainees and people outside detention facilities were deprived of proper medical care for their injuries

65 International Criminal Tribunal for the former Yugoslavia, Prosecutor v. Dario Kordić and Mario Cerkez, No. IT-95-14/2-T, Trial Chamber, Judgment of 26 February 2001, para. 205.

66 International Criminal Tribunal for the former Yugoslavia, Prosecutor v. Momčilo Krajišnik, No. IT-00-39-T, Trial Chamber, Judgement of 27 September 2006. See in particular paras. 736, 755-756, 757-761, 765-772 and 773-779.

67 International Criminal Tribunal for the former Yugoslavia, Prosecutor v. Radoslav Brđanin, No. IT-99-36-T, Trial Chamber, Judgement of 1 September 2004. See in particular paras. 1021,1024 and 1046-1050. 
and illnesses. For the Chamber "proper medical care was deliberately withheld from Bosnian Muslims and Bosnian Croats by the Bosnian Serb authorities for the very reason of their ethnicity." The cumulative effect of this conduct, in addition to the denial of other fundamental rights, the rights to employment, freedom of movement and proper judicial process, amounted to persecution as a crime against humanity. ${ }^{68}$

In Brđanin, the prosecutor also charged the accused with persecution as a result of "the destruction of, or wilful damage to, Bosnian Muslim and Bosnian Croat religious and cultural buildings," which could be considered to entail a violation of cultural rights. The Chamber was convinced beyond reasonable doubt that the destruction of cultural property took place with the intent to discriminate on racial, religious or political grounds. ${ }^{69}$

In Popović et al., ${ }^{70}$ the last Srebrenica case decided by the Trial Chamber at the Tribunal, and currently under appeal, the Chamber held that crimes against humanity took place on several grounds, two of which are connected to deprivations of economic and social rights. First, on the ground of cruel and inhuman treatment since male detainees in different locations "had little, if any, food, water or medical treatment [and] some prisoners were so thirsty that they drank their own urine." For the Chamber, such treatment "constitutes a blatant denial of fundamental rights that had a severe impact on the victims." The second ground was the forcible transfer of people from Srebrenica and Žepa to other places such as Potočari. The Chamber held that people in these enclaves had been intentionally deprived of the most basic things for survival like shelter, medicine, food and water, and of humanitarian assistance to force them to leave the towns.

The Special Court for Sierra Leone has also made findings on crimes against humanity involving infringement of economic and social rights,

68 Although the Chamber found that denial of proper medical treatment could be a basis for persecution, there was insufficient evidence to establish individual responsibility for the violation of the right to proper medical care. See ibid., para. 1076.

69 See also Prosecutor v. Dario Kordić and Mario Čerkez, paras. 206-207.

70 International Criminal Tribunal for the former Yugoslavia, Prosecutor v. Popović et al., No. IT-05-88-T, Trial Chamber, Judgement of 10 June 2010, paras. 993-994 and 1085. 
particularly labour rights. In Sesay, Kallon and Gbao, the Trial Chamber found, for example, that forced farming, mining and military training constituted the crime against humanity of enslavement. ${ }^{71}$

In addition, in the case of Kaing Guek Eav (alias "Duch"), ${ }^{72}$ the Trial Chamber of the Extraordinary Chambers in the Courts of Cambodia found that the crime against humanity of "other inhumane acts" as a form of persecution included means employed by the accused to deliberately deprive victims of adequate food, sanitation and medical services, in order to control the prison population under his authority, and eventually lead to their deaths.

The Rome Statute (art. 7) includes several underlying offences for crimes against humanity which may incorporate violations of economic, social and cultural rights. ${ }^{73}$

\section{(b) Genocide}

Violations of economic, social and cultural rights may also be present in the crime of genocide, notably the underlying offence of "deliberately inflicting on the group conditions of life calculated to bring about its physical destruction in whole or in part" ${ }^{74}$

In the case of Akayesu, the International Criminal Tribunal for Rwanda considered that "subjecting a group of people to a subsistence diet, systematic expulsion from homes and the reduction of essential medical

71 Prosecutor v. Issa Hassan Sesay, Morris Kallon and Augustine Gbao, No. SCSL-04-15-T, Trial Chamber I, Judgement of 25 February 2009, paras. 1118-1121, 1215-1217, 1476-1477, 1588-1591, 1414-1443.

72 Kaing Guek Eav alias "Duch", No. 001/18-07-2007/ECCC-TC, Trial Chamber, Judgement of 26 July 2010, paras. 257-274.

73 Enslavement; deportation or forcible transfer of population; other inhumane acts of a similar character intentionally causing great suffering, or serious injury to body or to mental or physical health; and persecution.

74 See Convention on the Prevention and Punishment of the Crime of Genocide, art. 2 (c); Statute of the International Criminal Tribunal for the former Yugoslavia, art. 4 (2) (c); Statute of the International Criminal Tribunal for Rwanda, art. 2 (2) (c); and the Statute of the International Criminal Court, art. 6 (c). 
services below minimum requirement" 75 was an example of deliberately inflicting such conditions. The Tribunal arrived at a similar view in other cases, such as Kayishema. ${ }^{76}$ The International Criminal Tribunal for the former Yugoslavia also arrived at the same determination in Brđanin. ${ }^{77}$

Suppressing cultural rights has also been considered to be evidence of the intent to destroy a group. At the Extraordinary Chambers in the Courts of Cambodia, the Closing Order in the case of Nuon Chea, leng Sary, leng Thirith and Khieu Samphan includes allegations of the deprivation of the right of Cham Muslims to take part in cultural life through the suppression of their traditions and language, and the forcible movement of Cham communities in order to disperse the group. ${ }^{78}$

\section{(c) War crimes}

As already noted, the rights to property and housing are often violated during conflict. The Statute of the International Criminal Tribunal for the former Yugoslavia incorporates a number of war crimes that deal with the destruction of property, housing, educational facilities and religious, historical or cultural property. ${ }^{79}$ For example, the Tribunal has jurisdiction over "extensive destruction and appropriation of property, not justified by military necessity and carried out unlawfully and wantonly" (art. 2 (d)); "wanton destruction of cities, towns or villages, or devastation not justified by military necessity" (art. 3 (b)); "seizure of, destruction or wilful damage done to institutions dedicated to religion, charity and education, the arts

75 International Criminal Tribunal for Rwanda, Prosecutor v. Akayesu, No. ICTR-96-4-T, Trial Chamber, Judgement of 2 September 1998, paras. 505-506. See also International Criminal Tribunal for the former Yugoslavia, Prosecutor v. Stakić, No. IT-97-24-T, Trial Chamber, Judgement of 31 July 2003, para. 517.

76 Prosecutor v. Kayishema et al., No. ICTR-95-1-T, Trial Chamber II, Judgement of 21 May 1999, para. 116.

77 Prosecutor v. Brđanin, para. 691.

78 Nuon Chea, leng Sary, leng Thirith and Khieu Samphan, No. 002/19-09-2007-ECCCOCIJ, Closing Order of 15 September 2010, para. 1341.

79 Article 2 of the Statute gives the Tribunal jurisdiction over grave breaches of the 1949 Geneva Conventions, and article 3 gives it jurisdiction over violations of the laws and customs of war. 
and sciences, historic monuments and works of art and sciences" (art. 3 (d)) and "plunder of public or private property" (art. 3 (e)).

In Brđanin, ${ }^{80}$ for example, the Trial Chamber found the accused guilty of aiding and abetting the war crimes of wanton destruction of cities and towns not justified by military necessity, and destruction of religious sites. The Chamber arrived at similar findings in Kordić and Čerkez, ${ }_{1}^{81}$ in addition to the finding that the accused were guilty of the war crime of plunder.

It should also be noted that Charles Taylor, the former President of Liberia, faced charges including having provided crucial support to a non-State armed group, the Revolutionary United Front, and having obtained plundered diamonds from this group. ${ }^{82}$ In this regard, the Trial Chamber of the Special Court for Sierra Leone found that Charles Taylor was responsible for aiding and abetting the Revolutionary United Front in Sierra Leone in exchange for access to resources, including diamonds. ${ }^{83}$ Under international criminal law, unlawful appropriation of property includes the "widespread and systematized acts of dispossession and acquisition of property in violation of the right of the owners and isolated acts of theft or plunder by individuals for their private gain. " ${ }^{84}$ Either form of plunder could substantially affect the enjoyment of economic, social and cultural rights. Plunder of diamonds, for example, could have a serious impact on the available economic resources in a State so as to limit or severely restrict its capacity to comply with its international human rights obligations.

At the International Criminal Court, 7 out of 28 indictees have been charged with crimes affecting economic and social rights, including destruction of property and pillage. While the proceedings against two defendants, Germain Katanga and Jean-Pierre Bemba, are ongoing, the other individuals indicted for pillage and destruction of property remain at large.

\footnotetext{
80 Prosecutor v. Brđanin, paras. 591-599 and 600-678.

81 Prosecutor v. Kordić and Čerkez, paras. 803-809.

82 The Prosecutor v. Charles Ghankay Taylor, Prosecution Final Trial Brief, paras. 18-21.

83 The Prosecutor v. Charles Ghankay Taylor, No. SCSL-03-01-T, Trial Chamber II, Judgement of 18 May 2012, paras. 6948-6952.

84 Prosecutor v. Kordić and Čerkez, para. 352.
} 
Some other war crimes in the Rome Statute with an economic and social rights dimension are: unlawful deportation; transfer or displacement; attacking civilian and protected objects; destroying or seizing the enemy's property; using poison, for example to poison water sources; and starvation as a method of warfare. ${ }^{85}$

\section{REPARATIONS}

Redress for large-scale violations of economic, social and cultural rights has been the exception in transitional justice. Nevertheless, some of the reparations for violations of civil and political rights have had a positive impact on economic, social and cultural rights. This section looks at reparations that have been ordered by justice mechanisms (tribunals) or administrative reparations programmes that address the root causes of conflict or repression or which have been awarded for violations of economic, social and cultural rights.

\section{The Inter-American Court of Human Rights}

Reparations awarded by the Inter-American Court have incorporated the realization of economic, social and cultural rights in important and innovative ways. The case of the Plan de Sánchez Massacrev. Guatemala ${ }^{86}$ constitutes a landmark in this regard. It concerns the massacre in 1982 of more than 268 indigenous people by the Guatemalan military and others, and the denial of justice for these crimes. Guatemala recognized its international responsibility in the case.

The Court aimed to rectify the vulnerable situation of the surviving victims and took into account that the massacre "gravely affected the identity and values of the members of the Maya-Achí people", thus recognizing the infringement

85 See article 8 (2) (a) and (b) relating to international armed conflicts, and article 8 (2) (e) relating to conflicts not of an international character. In relation to war crimes in international armed conflict, the provisions of the Rome Statute are derived from international humanitarian law, including the grave breaches regime in the four Geneva Conventions of 1949 and Additional Protocol I (art. 85).

86 Plan de Sánchez Massacre v. Guatemala, Judgement of 19 November 2004, Series C, No. 116, in particular paras. 81, 100, 104-105, 107 and 110. 
of cultural rights. The Court recognized that during the massacre vast damage was caused to all things that made the livelihood of the community possible; it therefore awarded $\$ 5,000$ to each victim for pecuniary damage.

The Court also ordered individual and collective reparation for nonpecuniary damage. It awarded $\$ 20,000$ to each victim, in part for the damage caused to their culture. It also ordered other forms of reparation, some of which are intrinsically connected to the realization of economic, social and cultural rights.

To redress damage to cultural rights, the Court ordered Guatemala to carry out a public act in Spanish and Maya-Achí and with members of the affected communities, acknowledging its international responsibility for the violations in Plan de Sánchez. It also ordered the translation and publication of the judgement in Maya-Achí, and $\$ 25,000$ to be given to the community for the chapel in which victims pay homage to those massacred as a guarantee of non-repetition.

Other forms of reparation were also related to economic and social rights, in particular the rights to housing and health. The Court ordered the implementation of a housing programme "to provide adequate housing to the surviving victims." A footnote refers to the meaning of "adequate housing" under general comment No. 4 (1991) of the Committee on Economic, Social and Cultural Rights. Moreover, the Court ordered the State to provide surviving victims with free specialized physical and mental health treatment, including medications, in agreement with each individual.

Finally, the Court ordered the State to implement certain development programmes "in addition to the public works financed by the national budget allocated to that region or municipality" that are intrinsically related to the enjoyment of economic, social and cultural rights. Those programmes included: a "sewage system and potable water supply", underlying determinants of the right to health and necessary for the realization of the right to water and sanitation; 87 the supply of intercultural

87 Committee on Economic, Social and Cultural Rights, general comment No. 14 (2000), para. 4. 
and bilingual teaching personnel for primary and secondary schools in the affected communities, which corresponds to the State obligation to "fulfil (facilitate) the acceptability of education by taking positive measures to ensure that education is culturally appropriate for minorities and indigenous peoples, and of good quality for all"; 88 and the establishment of a health centre with adequate personnel and conditions to provide medical and psychological services to victims, which helps to guarantee physical accessibility to health services among other things. ${ }^{89}$ It is clear that the Court intended not only to restore the situation ex ante, but also to rectify a situation that it considered contrary to the spirit of international human rights law.

\section{Administrative reparations programmes}

The reports of truth commissions often make recommendations to States on reparations, which then form the basis of administrative reparations programmes. In contrast to court-ordered reparations, these State-designed programmes aim at redressing in a similar way a multitude of victims for the harm caused by specific human rights violations, usually of civil and political rights.

Some programmes include different forms of reparation that could have an impact on the realization of economic, social and cultural rights and/or on the root causes of conflict and repression. Argentina, Chile, Guatemala, Peru and Sierra Leone have such programmes. Nevertheless, their impact on the realization of economic, social and cultural rights is to be examined with caution, given that reparations programmes in general face serious implementation and financing problems. Of all these programmes, Chile's is a good example of reparations linked to some economic, social and cultural rights. ${ }^{90}$

88 Committee on Economic, Social and Cultural Rights, general comment No. 13 (1999) on the right to education, para. 50.

89 Committee on Economic, Social and Cultural Rights, general comment No. 14 (2000), para. 12 (b) (ii).

90 Elizabeth Lira, "The reparations policy for human rights violations in Chile", in The Handbook of Reparations, P. De Greiff, ed. (Oxford, Oxford University Press, 2006). 
In Chile, the National Commission of Truth and Reconciliation was established to expose the truth about serious human rights violations such as enforced disappearances and arbitrary killings. It made detailed recommendations on reparations in its final report in 1991. The National Commission recommended that the State should adopt measures to improve the welfare of the victims living in Chile in areas such as social security, health, education and housing. ${ }^{91}$

As a result of these recommendations, Parliament passed Law 19.123 on 8 February 1992, creating the National Corporation for Reparations and Reconciliation and establishing the forms of reparation to the victims listed in the National Commission's report or recognized by the Corporation. The Law aimed to provide a certain level of economic stability to surviving victims. The Law provided for a monthly pension, a one-off payment equivalent to 12 months' pension, and access to educational and health benefits.

The health service, known as the Programme of Reparation and Integral Health Care (PRAIS), goes beyond access to primary health care for different members of the family of the deceased. It includes in-patient treatment, dental services and access to specialist services even for conditions not caused by the violations. The children of the deceased up to the age of 35 were given the right to free education not only at the primary level, as required by international standards, but also at secondary and university levels. Students also received a monthly stipend.

The situation of torture survivors and their next of kin was only partially addressed in 2004, when the Valech Commission was established and Parliament adopted Law 19,992. Torture survivors and some of their next of kin were to be provided with some form of reparation, including access to PRAIS.

Another important reparation measure adopted in Chile applied to those who were unfairly dismissed from their jobs for political reasons during the dictatorship (exonerados políticos). Unfair dismissal constitutes a violation

91 Informe de la Comisión Nacional de Verdad y Reconciliación, vol. II, pp. 1258-1266. 
of the right to work and, in Chile, such dismissals also had a detrimental impact on victims' social security benefits, particularly their pensions. Therefore, in 1993, Parliament passed Law 19,234 ordering the payment of reparation to persons dismissed for political reasons who met certain requirements. Such reparations included a monthly pension for life and a one-off payment.

As in Chile, the Truth and Reconciliation Commission in Peru, in its final report (2003), recommended the creation of a reparations programme to the Government. ${ }^{92}$ The programme was established through Law 28,592 in 2005. It incorporates individual and collective reparations and a broad concept of victims and beneficiaries (arts. 3, 6-7), excluding members of "subversive groups" (art. 4). Implementation began in 2007.

The Peruvian programme, like that of Chile, includes individual reparations related to health, education and housing rights, but in contrast to Chile's, it is one of the few through which the State provides collective reparations. Such reparations even considered the effect of the violations on the cultural life of the communities concerned. The Truth and Reconciliation Commission found that the main victims of the conflict were peasants and indigenous people, who were affected both individually and collectively. ${ }^{93}$ Therefore, the Truth and Reconciliation Commission considered that the communities should receive collective reparations.

Law 28,592 defined collective victims as those communities (indigenous or not) that had been subjected to multiple human rights violations and suffered serious damage to the family or community structure (art. 7). Such communities have received financial support to carry out infrastructure projects or develop basic services, as decided by themselves. ${ }^{94}$ In this way, the State consciously linked collective reparations to development and the enjoyment of some economic, social and cultural rights. The cost

\footnotetext{
92 Report of the Peruvian Truth and Reconciliation Commission, vol. IX, chap. 2.2.

93 lbid., p. 194.

94 See Peru, Decree No. 015-2006-JUS, arts. 25-29, and Secretaría Ejecutiva, Comisión Multisectorial de Alto Nivel, "Lineamientos generales del Programa de Reparaciones Colectivas" (Lima, September 2009), p. 7.
} 
of the project per community was 100,000 nuevos soles (approximately $\$ 35,000)$. While the costs have been relatively low, more than 1,400 communities and more than 600,000 victims have benefited. Importantly, communities have preferred infrastructure projects. ${ }^{95}$

In Sierra Leone, a country with considerably fewer economic resources than Chile or Peru and where the enjoyment of economic, social and cultural rights faces more challenges, the Lomé Peace Agreement and the Truth and Reconciliation Commission also called for reparations. The Commission's report, 96 in particular, highlighted that, given the economic difficulties to provide reparations to all victims, reparations should benefit the most vulnerable, such as "amputees, war wounded, women who suffered sexual abuse, children and war widows."

The Commission recommended different forms of reparation such as "health care, pensions, education, skills-training and microcredit/projects, community and symbolic reparations", but no cash payments. It emphasized that rehabilitation and the provision of services were necessary for the most vulnerable victims as a way of improving their quality of life.

While the Commission acknowledged the lack of economic resources to provide reparations to all victims, it emphasized that reparations are "primarily the responsibility of the Government," which should acknowledge the harm suffered. Implementation of the reparations programme began in November 2008. Most of the funding available to provide reparations comes from the United Nations Peace Building Fund, which sees reparations as an element to enhance reconciliation and consolidate the peace process.

In Morocco, the Equity and Reconciliation Commission and its Follow-up Committee have followed a similar path, by proposing collective reparations

95 Aprodeh and International Center for Transitional Justice, "Sistema de vigilancia de reparaciones: reporte nacional de vigencia del programa de reparaciones colectivas etapa II", April 2009, p. 51.

96 Witness to Truth: Report of the Sierra Leone Truth and Reconciliation Commission, vol. II, chap. 4, in particular paras. 6, 22-26, 33, 57, 82 and 100. 
to address the direct or indirect suffering that victims have experienced as a result of political violence and of the ensuing human rights violations.

\section{INSTITUTIONAL REFORM}

Guarantees of non-repetition are essential to combat impunity for violations of human rights and humanitarian law and to effectively tackle the root causes of conflict and repression. While they are a form of reparation, they fulfil other aims such as preventing such violations from happening again. They are also forward-looking as they benefit society as a whole, and not only victims. In the context of transitional justice, institutional reform refers to guarantees of non-repetition aimed at reforming State structures and institutions that facilitated or promoted such violations.

According to principle 36 of the principles to combat impunity, "States must take all necessary measures, including legislative and administrative reforms, to ensure that public institutions are organized in a manner that ensures respect for the rule of law and protection of human rights." This principle establishes that States should ensure: vetting; an independent and impartial judiciary; civilian control of the military and other enforcement personnel; complaint procedures; and the training of relevant State personnel in human rights and humanitarian law. Nevertheless, the commentary on the updated principles particularly notes that institutional reform should be of a "comprehensive" nature for it to be "a foundation for sustainable justice." 98 Therefore, institutional reform should deal not only with the structural transformation of those State institutions that participated (by action or omission) in violations of human rights and humanitarian law but, more importantly, also with the root causes of conflict or repression in order to prevent further violations.

Institutional reform is a key dimension of transitional justice because it has the potential to trigger structural change. However, it is one of the

\footnotetext{
97 "Updated Set of principles for the protection and promotion of human rights through action to combat impunity" (E/CN.4/2005/102/Add.1).

98 "Report of the independent expert to update the Set of Principles to combat impunity, Diane Orentlicher" (E/CN.4/2005/102), para. 66.
} 
most underresearched and unexplored areas. To date, most efforts have focused on vetting, security sector reform and legislative reform, leaving other structures and laws that made repression and conflict possible largely untouched. Experience shows that vetting, security sector reform and legislative reform are necessary, but that additional measures might be needed. As guarantees of non-repetition are broadly defined, and can be carefully considered and crafted, they have a great potential to address the root causes and violations of economic, social and cultural rights. Politically it might be a challenge, but transitional justice actors need to gain understanding of the relevance of these dimensions and of the best ways to address them.

This section looks at the experiences in Nepal, a country still in the early stages of a transition, which began in 2006, and in South Africa, where almost two decades have passed since the transition began. Both illustrate the challenges in the design and implementation of institutional reform that tackles root causes and violations of economic, social and cultural rights.

\section{Nepal and institutional reform}

The Comprehensive Peace Agreement between the Government of Nepal and the Communist Party of Nepal (Maoist) was signed in November 2006 to end the decade-long armed conflict in the country. During those years, people were systematically killed, disappeared, internally displaced or forcibly recruited, among other violations. At the heart of the conflict were discrimination, inequality, poverty and lack of enjoyment of economic, social and cultural rights resulting from the caste, ethnicity, gender and class systems in Nepal, which affected, in particular, members of low castes, known as Dalits, and minorities. ${ }^{99}$

The Agreement is unique since it puts economic and social transformation at the centre of the peace process, creating a roadmap for the transition. It explicitly calls for the establishment of a political system that fully complies with universally accepted human rights (sects. 3.4

99 Tafadzwa Pasipanodya, "A deeper justice: economic and social justice as transitional justice in Nepal", International Journal of Transitional Justice, vol. 2, No. 3 (December 2008). 
and 7.1.2) and ends discrimination (sect. 3.5); and for the protection of the rights to education, shelter, food security, social security, health and employment as well as for land reform (sects. 3.9 and 7.5). It goes as far as recognizing that there are vulnerable groups in society in particular need of socioeconomic security and notes the relevance of combating corruption.

More importantly, the Agreement also envisages the establishment of transitional justice mechanisms, with potential relevance for securing social and economic transformation. It refers, for instance, to the establishment of a truth and reconciliation commission, a national peace and rehabilitation commission, and a high-level State restructuring recommendation commission (sect. 8).

While the Agreement is ambitious and holistic, legislative reform on social and economic issues has been minimal. A good example of legislative reform is the 2007 Interim Constitution of Nepal, which includes diverse economic, social and cultural rights and enforcement mechanisms. The Interim Constitution incorporates, for example, the rights to equality and non-discrimination, to a clean environment and health, to education and cultural rights, and to work and social security. Furthermore, it grants jurisdiction to the Supreme Court to consider violations of fundamental rights and to interpret the Constitution; and to the National Human Rights Commission to "ensure the respect for, protection and promotion of human rights and their implementation" (part 15, art. 132). The Interim Constitution also includes a section on key policies to be developed by the State relevant to economic, social and cultural rights.

It was intended that the Interim Constitution would be finalized by the Constituent Assembly in 2010. However, after failing to agree on its provisions, the Constituent Assembly was dissolved in May 2012. Elections for a new Assembly were held on 19 November 2013 and negotiations are expected to continue once the Assembly is reconvened.

Another example of crucial legislative reform in the area of economic, social and cultural rights is the 2011 Caste-based Discrimination and 
Untouchability (Offence and Punishment) Act. Apart from these examples, there has been no new legislation relevant to transitional justice and economic, social and cultural rights.

At the institutional level, reforms are still expected. For example, no truth and reconciliation commission has been established because it has been under debate since early 2010 . The draft bill refers to gross and serious human rights violations but not specifically to economic, social and cultural rights. It includes, nevertheless, jurisdiction over crimes such as looting or seizure of private or public property and forced eviction from housing or land, which, as noted previously, constitute violations of the rights to housing and property, and are relevant to the enjoyment of other economic, social and cultural rights. However, transitional justice in $\mathrm{Nepal}$ has not developed holistically so as to put into effect the social, economic and cultural goals incorporated in the Agreement. Therefore, if important changes are not put in motion in the coming years, the opportunity provided by the Agreement and the Interim Constitution to address the root causes of conflict and systemic violations of economic, social and cultural rights will be lost.

\section{South Africa and institutional reform}

South Africa has undergone several reforms since apartheid ended, some of which aimed to address the root causes of conflict and violations of economic, social and cultural rights. While their success can be questioned, they have not been given enough attention in the transitional justice literature. This is regrettable, since the South African experience illustrates the challenges in these areas.

Apartheid was a legal, social, economic, political and cultural system that permitted the discrimination of black people in South Africa. By the time Nelson Mandela assumed power in 1994, he "inherited the most developed economy in Africa" but also "major socioeconomic problems, including high levels of unemployment, the abject poverty of 50 per cent of the population; sharp inequalities in the distribution of income, property, 
and opportunities; and high levels of crime and violence," all of which affected in particular the black population. ${ }^{100}$

Ending apartheid required structural reforms in different areas. Commitment to equality and non-discrimination was essential. As in Nepal, the reform began at the constitutional level with the adoption by Parliament of the Interim Constitution (Act 200 of 1993). This text contained a chapter on fundamental rights, which incorporated the right to equality and non-discrimination and economic, social and cultural rights. The Interim Constitution recognized the justiciability of all fundamental rights without any distinction. Furthermore, it established the Constitutional Court tasked to protect the fundamental rights and freedoms under the Constitution. ${ }^{101}$ The Interim Constitution was in force from April 1994 until February 1997.

In 1996, the Constitutional Assembly promulgated the new South African Constitution (Act 108), which took effect in February 1997. Key to the new Constitution was the recognition of economic, social and cultural rights as fundamental rights. The Constitution included the right to equality and non-discrimination, to health care, to a healthy environment, to food, to water, to adequate housing and social security as well as the right to a language and culture of one's choice.

Its section 38 provides that all rights in the Bill of Rights are justiciable. It lists the persons who may "approach a competent court, alleging that a right in the Bill of Rights has been infringed or threatened, and the court may grant appropriate relief, including a declaration of rights." The Constitution also maintained the Constitutional Court and created a number of human rights institutions, such as the South African Human Rights Commission, the Commission for the Promotion and Protection of the Rights of Cultural, Religious and Linguistic Communities, and the Commission for Gender Equality.

100 Sampie Terreblanche, A History of Inequality in South Africa 1652-2002 (Pietermaritzburg, South Africa, University of Natal Press and KMM, 2002), p. 4.

101 Speech by Nelson Mandela at the Inauguration of the Constitutional Court, 14 February 1995. Available from www.constitutionalcourt.org.za/site/thecourt/mandelaspeech. html (accessed 30 October 2013) 
South Africa also implemented other measures to fight the legacy of apartheid, including in relation to land distribution. ${ }^{102}$ Indeed, "by 1990 South Africa was marked by a stark racial divide between the 13 per cent of land reserved for black occupation and the remainder in so-called white South Africa, dominated by 60,000 commercial farms covering 70 per cent of the country's area." 103 Institutional reform measures were incorporated very early on in the transition through the Interim Constitution. Its section 28 covered the right to property, and sections 121 to 123 dealt with the restitution of land rights. They foresaw the enactment of a land restitution act and the establishment of a commission on restitution of land rights.

The Restitution of Land Rights Act (Act 22 of 1994) was approved by the new democratic Parliament and constituted an "ambitious programme of redress, reconciliation, and reconstruction."104 The Act recognizes the enforceable right of the dispossessed, their direct descendants as well as communities to land restitution or compensation for land that was lost owing to racial discrimination (sect. 2 (1)). It established the Commission on Restitution of Land Rights and the Land Claims Court. The former was created to receive and investigate claims, to help the parties in presenting their claims, and to advise the Court. The Act applied to claims of people who lost their land between 19 June 1913 and the deadline for receiving claims.

The Commission began work in 1995. Between 1995 and 2005, it officially registered 79,696 claims, most of which have been settled. Nevertheless, according to some estimates, these claims represent only about 10 per cent of those with a legitimate claim over land. ${ }^{105}$ Restitution

102 Terreblanche, A History of Inequality, pp. 5-8; 260-264.

103 Ruth Hall, "Reconciling the past, present and future: the parameters and practices of land restitution in South Africa", in Land, Memory, Reconstruction, and Justice: Perspectives on Land Claims in South Africa, C. Walker and others, eds. (Ohio University Press, 2010), p. 19.

104 C. Walker and others, eds., Land, Memory, Reconstruction and Justice: Perspectives on Land Claims in South Africa, p. 1.

105 Hall, "Reconciling the past", p. 23. 
has been understood in very broad terms as proper restitution of the lost land if the current owner accepts to sell at the price offered by the State, or alternative land, compensation or a combination of these. In practice, compensation has prevailed. The problem with compensation is that it defeats the original purpose of the reform and maintains the status quo. Furthermore, compensation is often low, and thus may not greatly improve victims' lives. ${ }^{106}$ Land restitution is not sufficient to facilitate victims' enjoyment of economic, social and cultural rights. Other means are necessary to enable victims to make a decent living and to have access to health and social services. Partial adjustments have been introduced to the restitution process, in order to ensure that it is conducive to development. ${ }^{107}$

Most of the reforms mentioned, such as the land restitution, began before the establishment of the Truth and Reconciliation Commission in December 1995, and worked in parallel with it. Nevertheless, the Truth and Reconciliation Commission also dealt with institutional reform in different areas, including economic, social and cultural rights and root causes of conflict. While it did not consider violations of economic, social and cultural rights, it emphasized that "the recognition and protection of socioeconomic rights are crucial to the development and sustaining of a culture of respect of human rights," and made different recommendations aimed at helping eradicate poverty and discrimination. It recognized that businesses and financial institutions should help in the reconstruction by making resources available to those most in need. For example, it recommended: the creation of a wealth tax; a one-off levy on corporate and private income; that companies listed on the Johannesburg stock exchange should make a contribution of 1 per cent of their market capitalization; the suspension of taxes on land and other donations made to discriminated people; and the creation of a business reconciliation fund to empower the poor. ${ }^{108}$

106 Ibid, p. 33.

107 Ruth Hall, "Land restitution in South Africa: rights, development, and the restrained State", Canadian Journal of African Studies, vol. 38, No. 3 (2004).

108 "Truth and Reconciliation Commission Report", vol. 5, chap. 8, in particular pp. 308 and 318-320. 
The Truth and Reconciliation Commission also recommended measures such as training in career development and professional skills for disadvantaged people and the elimination of child labour. In relation to land, it called for an audit of all unused and underused land so as to consider ways to make it available to landless people. It also made recommendations in relation to the right to health and health professionals. For example, it recommended that all health legislative reforms should focus on primary health care, that mental health should be given priority and be included in primary health care and that mental services should be available to all. It also called for a change in the existing disparities in health-care allocation. Finally, it also recommended that South Africa should ratify the International Covenant on Economic, Social and Cultural Rights. ${ }^{109}$

109 Ibid., pp. 313, 319, 321, 334-340 and 348. 


\section{CONCLUSIONS}


This publication shows that transitional justice processes increasingly address economic, social and cultural rights issues, either as part of the root causes of conflict and repression or as violations occurring during the conflict. However, there continue to be different challenges that need to be addressed in theory and in practice.

A first challenge is the need to prioritize the violations that will be included in transitional justice processes. It is important to identify criteria that could help stakeholders decide when to include violations of economic, social and cultural rights in transitional justice processes and how best to do so. If transitional justice aims to deal with large-scale atrocities, or with violations that are particularly characteristic of the conflict or repression, and these include violations of economic, social and cultural rights, then it should also deal with violations of these rights-as shown for example in Timor-Leste. As with violations of civil and political rights, not all violations of economic, social and cultural rights need to be included, but only those that are large-scale or particularly relevant to the specific situation.

Lack of knowledge among transitional justice stakeholders of economic, social and cultural rights and of the mechanisms available to protect them constitutes another challenge. Unpacking the obligations deriving from such rights as well as understanding the United Nations and regional mechanisms able to strengthen their protection is essential. Some types of economic, social and cultural rights violations are more likely to be dealt with by transitional justice processes: for example, violations of State obligations to respect economic, social and cultural rights, and to protect them when the State was in a position to do so, violations of the prohibition of discrimination or gross failure to comply with minimum core obligations while illegal diversion of existing resources was apparent.

A related problem lies in the institutional capacity of the different transitional justice mechanisms. All have the potential to address violations of economic, social and cultural rights and root causes to some extent but they face different limitations, ranging from a lack of human or financial resources to the nature of their mandates. Such limitations must be taken into account. 
Here are some of the lessons learned from the experiences considered in this publication.

\section{TRUTH}

Addressing the root causes of conflict appears to be an important function of truth commissions. If economic, social and cultural rights violations or gross failure to realize them were part of the root causes of the conflict or repression, not considering them in the mandate of truth commissions may lead to incomplete or biased accounts of the historical truth which truth commissions seek to bring to light. The truth commissions referred to in this publication took different approaches to including economic, social and cultural rights-related issues in their work. Some limited their work to including some references to economic, social and cultural rights-related issues in order to offer a more holistic picture of the causes of conflict or repression and of those responsible-perhaps with the aim of better elucidating violations of civil and political rights.

In contrast, investigating violations of economic, social and cultural rights per se is newer to truth commissions, and there are thus fewer examples to draw upon. In this sense, the experiences of the Commission for Reception, Truth and Reconciliation in Timor-Leste and the Truth and Reconciliation Commission in Sierra Leone deserve close attention in the area of economic and social rights, and the Commission of Historical Clarification in Guatemala in relation to cultural rights. The Commission for Reception, Truth and Reconciliation in Timor-Leste and the Truth and Reconciliation Commission in Sierra Leone dealt with economic, social and cultural rights by prioritizing those violations that were more representative of systematic harm: in Timor-Leste, the rights to health, education and an adequate standard of living; in Sierra Leone, the right to property. Furthermore, the experience of the latter suggests that prioritizing some rights and trying to group them in particular categories like looting and property destruction helps to identify patterns of conduct and generalized violations. Perhaps as a result of the acknowledgment of their institutional limitations, truth commissions have been selective in the violations of economic, social and 
cultural rights they have investigated. This might be a lesson to consider when deciding the scope of future truth commissions.

Considering economic, social and cultural rights-related root causes and violations of these rights as part of the truth commissions' work has also focused more attention on the different actors (State and non-State) that are responsible for the conflict or repression and for the atrocities that took place. In particular, the role of non-State actors like corporations has gained attention, as was the case in Sierra Leone and Timor-Leste, while the Peruvian case extensively considered abuses committed by a guerrilla group.

\section{JUSTICE}

Justice mechanisms are not primarily designed to shed light on the root causes of conflict but rather to address specific cases of human rights violations (State responsibility) or crimes (individual criminal responsibility). In so doing, they may address economic, social and cultural rights violations, as suggested below.

Human rights courts could adjudicate on violations of economic, social and cultural rights if they have jurisdiction over such violations. The jurisprudence on large-scale violations of the rights to property and to health of the Inter-American Court of Human Rights, the Human Rights Chamber for Bosnia and Herzegovina or the Colombian Constitutional Court illustrates this. Additionally, criminal tribunals (domestic or international) can address violations of economic, social and cultural rights (or some aspects) if they constitute crimes. For example, the International Criminal Tribunal for the former Yugoslavia has held that violations of some economic, social and cultural rights can constitute the crime against humanity of persecution. Such possibilities need to be further explored to strengthen accountability for relevant violations of economic, social and cultural rights. Economic crimes also provide an opportunity to deal with possible violations of economic, social and cultural rights. 


\section{REPARATIONS}

Even where reparations have focused primarily on violations of civil and political rights, it is interesting to point out that such reparations have included access to services or goods (such as health, education or housing), thus allowing victims to enjoy some of their economic, social and cultural rights. Reparations can help to realize some economic, social and cultural rights, but they do so in a reactive way: they respond to an existing violation of an international obligation-usually of a civil or political right-and normally have a defined time frame. This might create tensions between the right to reparation in the context of transitional justice and the economic, social and cultural rights obligations at stake: the limited scope of reparations in the context of transitional justice is unlikely to capture the whole range of obligations regarding economic, social and cultural rights. Therefore, contextual factorssuch as the general level of realization of economic, social and cultural rights and the available resources-should be taken into account when designing adequate remedies for a given situation. Furthermore, reparations are unlikely to fundamentally alter the structural situation of discrimination, poverty or lack of services in which most victims find themselves, even if they can and do trigger important changes, particularly through guarantees of non-repetition of violations. Reparations can also serve to publicly acknowledge the violations and the victims' suffering.

The absence of adequate guarantees of non-repetition addressing the root causes that led to conflict in the first place is visible in some of the experiences considered in this publication. Without adequate guarantees of non-repetition, the impact of reparations on the enjoyment of economic, social and cultural rights is substantially diminished. However, such a failure might reveal the lack of political will to use one of the most transformative dimensions of reparations.

\section{INSTITUTIONAL REFORM}

Institutional reform is one of the most underresearched and unexplored areas of transitional justice despite being necessary to achieve lasting 
change after conflict or repression. While institutional reform has largely focused on legislative reform, security sector reform and vetting, this publication has provided examples of institutional reforms in States undergoing transitions that go further and deal with the root causes of conflict and economic, social and cultural rights. Indeed, in South Africa and Nepal, a broad range of reforms were envisaged to tackle poverty and discrimination, thereby recognizing the centrality of economic, social and cultural rights. In Nepal, it is to be noted that institutional reform measures were included in the Comprehensive Peace Agreement.

The experiences of South Africa and Nepal show the ways in which different institutional reform measures can be used to effect lasting change in society. However, they also remind us that institutional reform is a lengthy process: results might be perceived only in the mid and long term, provided that there is political will and adequate resources to carry them out. It is important to be aware of these limitations: institutional reform might not immediately produce significant social change.

\section{RECOMMENDATIONS}

- Awareness should be raised among stakeholders about the importance of including relevant violations of economic, social and cultural rights in transitional justice as well as about the latter's potential to deal with such violations. However, its potential to effect lasting changes in society should not be overestimated. Even if transitional justice mechanisms deal with root causes and violations of economic, social and cultural rights, their contribution to social change will continue to be modest though important.

- Different approaches could be taken to integrating economic, social and cultural rights in transitional justice. Depending on the context, addressing violations of economic, social and cultural rights as part of the root causes of the conflict is an option, as is addressing violations that took place during the conflict. Another consideration is that reparations could include restitution or the provision of services or goods that are typically components of economic, social and cultural 
rights - such as access to health or rehabilitation services, access to education or the restitution of housing. Integrating economic, social and cultural rights into transitional justice requires prioritizationincluding a careful consideration of the nature and the scale of the violations to be included-adequate mandates, tools and expertise to do so.

- A comprehensive treatment of the root causes of conflict or repression and large-scale violations of economic, social and cultural rights should involve the consideration of a whole range of transitional justice mechanisms, including institutional reform, and not minimalistic approaches where only truth commissions play a role.

- In-depth knowledge of economic, social and cultural rights, of the State obligations deriving from them, and of the international and regional mechanisms available to protect them, by transitional justice stakeholders is necessary to include economic, social and cultural rights in transitional justice more effectively. Equally, experts in economic, social and cultural rights, including those working for international and regional organizations, should learn more about transitional justice so that the two constituencies can work more closely together.

- Transitional justice mechanisms should consider selecting commissioners and/or appointing staff with expertise in economic, social and cultural rights and from different disciplines.

- More sustained research and work in the area of transitional justice, root causes and large-scale violations of economic, social and cultural rights are needed. While this publication has shed light on some important questions, it has not dealt with the issue exhaustively. Therefore, to bridge these areas more successfully, it is important to continue gathering relevant data and analysis on: 
(a) The potential of transitional justice mechanisms to address these issues;

(b) The best ways to address the connection between transitional justice, economic, social and cultural rights, and root causes;

(c) The criteria that should guide the inclusion of economic, social and cultural rights in transitional justice;

(d) The obstacles and challenges that should be overcome for a successful and adequate inclusion of these dimensions;

(e) A more detailed exploration of how violations of specific economic, social and cultural rights (e.g., the right to food, the right to health, the right to education, the right to housing or cultural rights) can be addressed in transitional justice;

(f) The involvement of non-State actors in economic, social and cultural rights violations or abuse. 

Designed and printed by the Publishing Service, United Nations, Geneva GE. 13-49839 - January 2014 - 2,826 - HR/PUB/13/5

United Nations publication

Sales No. E. 14.XIV.3

ISBN 978-92-1-154204-2 